\title{
Siebrandus Sixtius: evidence of rheumatoid arthritis of the robust reaction type in a seventeenth century Dutch priest
}

\author{
J Dequeker
}

\section{Abstract}

Rheumatoid arthritis of the robust reaction type has been diagnosed in a seventeenth century Dutch priest, Siebrandus Sixtius, based on pictorial evidence of typical hand deformities and historical evidence affirming that he had chronic nodular rheumatism for many years.

This case report, in conjunction with other pictorial depictions of probable rheumatoid arthritis, questions the view that rheumatoid arthritis is a modern disease which prevailed in the New World and was found in the Old World only after the discovery of America.

Some authorities believe that rheumatoid arthritis may have originated in the New World and entered the Old World after 1492. This belief arises from the absence of published reports describing unambiguous evidence of this disease in the Old World before $1800^{1}$ and the presence of an indistinguishable arthritis in the New World before $1492 .^{2}$ There is, however, very suggestive evidence of rheumatoid arthritis in the visual arts. ${ }^{3}$ Perhaps the most convincing evidence of the existence of rheumatoid arthritis can be seen in paintings such as the arthritis of the housemaid of Jacob Jordaens (1593-1678) which is recognisable in the painting of Jordaens's
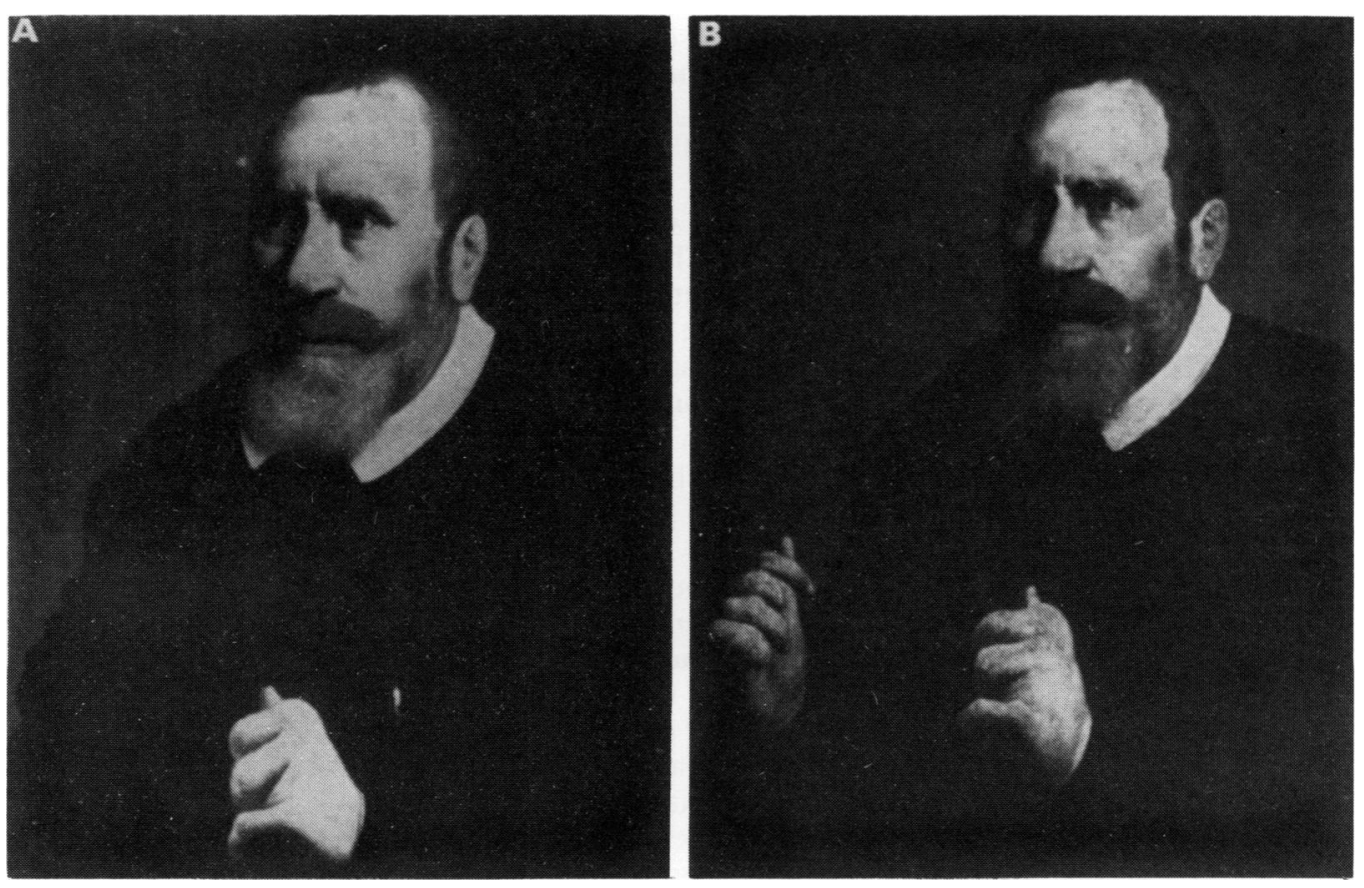

Two paintings of Siebrandus Sixtius. (A) Displayed at the Catharijneconvent Museum Utrecht, the Netherlands (copy of portrait B). (B) By Claes Cornelisz Moeyaert (1631), displayed in the Pastorie of the Begijnhof Amsterdam, the Netherlands. (Reproduced with permission.) own family (The Painter's Family, Madrid, Prado). Another very characteristic hand and wrist deformity of rheumatoid arthritis is seen at the Escorial Museum near Madrid in the painting St Anthony's Temptations by an anonymous artist of the Flemish-Dutch School of the mid-fifteenth or early sixteenth century. ${ }^{4}$

This paper describes the typical hand features of rheumatoid arthritis in a painting by Claes Cornelisz Moeyaert in 1631 , representing Siebrandus Sixtius, a Dutch priest, about whom there is historical evidence indicating that he had a severe chronic rheumatic disease.

\section{Case report}

The figure shows two paintings of Siebrandus Sixtius. Portrait $\mathrm{A}$ is at the Catherijneconvent Museum, Utrecht, the Netherlands and is a copy of portrait $B$ which is at the Pastorie of the Begijnhof, Amsterdam, the Netherlands. The diagnosis of rheumatoid arthritis is based on the typical hand deformities, swelling of the metacarpophalangeal joints, ulnar deviation of the fingers, and contractures, especially at the ring and fifth finger of the left hand. The right hand also shows contractures, especially of the second finger and swelling of the proximal interphalangeal joints.

Siebrandus Sixtius is the pseudonym for

Rheumatology Unit
and Arthritis and
Metabolic Bone Disease
Research Unit,
K U Leuven,
Universitair Ziekenhuis
Pellenberg,
B-3212 Pellenberg,
Belgium
J Dequeker
Accepted for publication
23 July 1991


Visscher Severinus who was born in Oosterwierum, Friesland, in 1568 and died in Amsterdam in January 1631. He studied theology at the Catholic University of Leuven, Belgium, and became the pastor and rector of the beguinage of Amsterdam in 1594. As a result of the Reformation he had a difficult time while serving the Catholic community as vicar general for Harlem, Leeuwarden and Groningen (1602). In 1601 and again in 1609 he had to go into hiding temporarily. Despite his reported illness at Cologne in 1609, he was invested with further duties as pastor of the St Nicholas parish in Amsterdam in 1610 and was appointed provisor of the Seminarium Hollandicum in 1612 and in 1617 the first provisor of the Collegium Pulcheriae or Holland College in Leuven.

Although he had numerous official duties, he did not forget his parishioners in Amsterdam. In a letter of 17 August 1628 to the Bishop Rovenius, his friend Jud Catsius mentioned that Sixtius would rather die than see one of his Amsterdam faithful die without the sacraments. His biography also mentioned that he heard confessions and performed other services during 28 consecutive nights. ${ }^{5}$

His biography notes the fact that because of hard work and the problems he encountered during his mission travels, he developed 'rheumatiek' (rheumatism) and 'knobbeljicht' (nodular gout). ${ }^{6}$

At the age of 62 he asked the Bishop to be relieved of his duties because of exhaustion. Six months later he died and at his funeral in Amsterdam, which was supposed to be held in privacy, a large crowd of people were present, indicating his popularity.

\section{Discussion}

The clinical signs on the portraits, together with the historical documents recording that he had nodular rheumatism, support strongly the view that Siebrandus Sixtius suffered from rheumatoid arthritis. This case report is the earliest (1631) fully documented, including imaging and historical evidence, description of rheumatoid arthritis. It predates by 170 years the detailed description of rheumatoid arthritis in the doctoral thesis of Landré-Beauvais ${ }^{7}$ and by more than 200 years Charcot's doctoral thesis ${ }^{8}$ on a series of 41 patients. This case report also antedates the probable description by Sydenham in $1676^{9}$ and Musgrave in $1703^{10}$ and the pictorial representation of a patient with rheumatoid arthritis in a painting by William Hoare in 1742, which hangs in the Royal National Hospital for Rheumatic Diseases in Bath. ${ }^{11}$

The diagnosis of rheumatoid arthritis in this case can be refined even further. The life story of Siebrandus Sixtius suggests that his rheumatoid arthritis is of the robust reaction type as described by de Haas et al, ${ }^{12}$ renowned rheumatologists from Amsterdam.

Robust type rheumatoid arthritis is usually seen in men and represents a special reaction to the disease of a strong body supported by a tough mind, but is in no other way a separate entity. There are usually substantial subcutaneous nodules previously called 'rheuma- tismus nodosus' or 'gout-like rheumatoid arthritis', and a high titre of rheumatoid factor. Rheumatoid factor could, of course, not be substantiated in this case, but the biography mentioned that Sixtius had nodular rheumatism. If the arthritis of Emperor Constantine IX (c. 980-1055) was rheumatoid arthritis, then the rheumatoid arthritis of the Emperor could also be classified as being of the robust reaction type, according to the detailed life style published by Caughey. ${ }^{13}$

The question of whether rheumatoid arthritis came from the New World to the Old World after the discovery of America can neither be fully refuted, nor supported by this seventeenth century case report. America was discovered by Christopher Columbus in 1492, 76 years before the birth of Siebrandus and New Amsterdam (New York) was founded by the first Dutch settlers in 1623, nine years before Siebrandus's death. It is unlikely that within the first 100 years after the discovery of America pathogens or allergens originally native to the New World could have been transplanted to the Old World and that, rheumatoid arthritis could be derived from these pathogens. Immigration to the New World was very limited before the eighteenth century and European soldiers returned only after the American Revolution (1775-83). Colonial transatlantic trade of potential agents of transportation of this disease such as tobacco, potatoes, deer, people, rodents, and dogs took place at a later date than the case of rheumatoid arthritis reported here and certainly later than the probable case of rheumatoid arthritis depicted in paintings of the Flemish-Dutch School of the fifteenth and sixteenth centuries.

Why rheumatoid arthritis is not depicted in works of art of earlier or later periods has something to do with the style of the painters. It is largely due to the realism of the Flemish, Dutch and Italian schools of the late Gothic era that we can recognise the rheumatoid deformities. On the contrary, during the Renaissance and the Baroque periods the figures were so idealised and perfected that signs of disease are seldom recognisable in them.

1 Short C L. The antiquity of rheumatoid arthritis. Arthritis Rheum 1974; 17: 193-205.

2 Rothschild B M, Turner K R, DeLuca M A. Symmetrical erosive peripheral polyarthritis in the late archaic period of Alabama. Science 1988; 241: 1498-1501.

3 Dequeker J. Arthritis in Flemish paintings (1400-1700). BMF 1977; 1: 1203-5.

4 Dequeker J, Rico-Lenza H. Evidence of rheumatoid arthritis in an early XVIth century painting of the Flemish-Dutch in an early XVIth century

5 De Katholiek 1866; 50: $104-5$.

6 Nieuw Nederlands Biografisch Woordenboek, 1918; IV: 1246-7.

7 Landré-Beauvais A J. Doit-on admettre une nouvelle espèce de goutte sous la dénomination de goutte asthémique primitive? Paris: Brison An VIII, 1800

8 Charcot J M. Etudes pour servir à l'histoire de l'affection décrite sous les noms de goutte asthémique primitive, nodosites de jointures, rhumatisme articulaire chronique (forme primitive) etc. Paris: Rignoux Imprimeur de la Faculté de Médecine de Paris, 1853

9 Sydenham T. The entire work of Dr. Thomas Sydenham, newly made English from the originals translated by fohn Swan. 3rd ed. London: Cave, 1753.

10 Musgrave W. De arthritide symptomatica dissertatio. Exeter: Yeo and Bishop, 1703.

11 Jayson M I V. The history of rheumatoid arthritis. Arthritis Rheum 1975; 18: 187-8.

12 De Haas W H D, De Boes W, Griffioen F, Oosten-Elst P. Rheumatoid arthritis of the robust reaction type. Ann Rheum Dis 1974; 33: 81-5.

13 Caughey D E. The arthritis of Constantine IX. Ann Rheum Dis 1974; 33: 77-80. 